\title{
Iridoids from Hymenodictyon floribundum
}

\author{
Cristina M. P. Borges, ${ }^{a}$ Carlos Diakanawma ${ }^{b}$ and Dina I. M. D. de Mendonça ${ }^{*, c}$ \\ ${ }^{a}$ Departamento de Química and ${ }^{b}$ Departamento de Biologia, Universidade Agostinho Neto, \\ Av. 4 de Fevereiro, 71, $2^{\circ}$ andar, CP 3244, Luanda, Angola \\ 'Departamento de Química, Universidade da Beira Interior, Rua Marquês d'Ávila e Bolama, \\ 6200-001 Covilhã, Portugal
}

\begin{abstract}
Das cascas do tronco e das folhas do Hymenodictyon floribundum B. L. Rob foram isolados dois novos iridoides, floribundano A (1) e floribundano B (2), e três compostos conhecidos, lupenona (3), escopoletina (4) e 4,5-di-hidroblumenol A (5). As estruturas de todos os compostos foram estabelecidas com base nos seus dados espectroscópicos.
\end{abstract}

Two new iridoids floribundane A (1) and floribundane B (2) and the known compounds lupenone (3), scopoletin (4) and 4,5-dihydroblumenol A (5) were isolated from trunk bark and leaves of Hymenodictyon floribundum B.L. Rob. The structures of all compounds were established from their spectroscopic data.

Keywords: Hymenodictyon floribundum, monoterpenes, secoiridoids, nitrogen-containing iridoid, C-9 iridoid

\section{Introduction}

The Hymenodictyon genus comprises 22 species. Of these, 11 are endemic to Madagascar, 4 to Asia and 7 to Tropical Africa. ${ }^{1}$ Hymenodictyon floribundum B.L. Rob. (Rubiaceae), endemic to Tropical Africa, is a small tree that grows in the mountains of the Huíla province and its traditional name is NDambi Yov`olwi, (omu)Lia-tyimeme. Its trunk bark is used in Angola folk medicine to treat fever. ${ }^{2}$

A previous study has shown that the trunk bark of this tree contains scopoletin, hymeselsin, scopolin and 3-O- $\beta$ D-glucopyranosyl- $\beta$-sitosterol. ${ }^{3}$ An exhaustive literature review revealed that, with the exception of an ongoing study examining the trunk bark and dried leaves of Hymendictyon floribundum (in the context of other medicinal plants of Angola), ${ }^{4}$ other parts of the tree have not yet to be studied.

In the aforementioned study, powdered trunk barks and dried leaves were extracted by maceration with methanol. The methanol extract was partitioned with hexane and chloroform. The hexane extract from trunk barks yielded lupenone $(3)^{5}$ and the chloroform extract yielded scopoletin (4). ${ }^{6}$ The chloroform extract from dried leaves yielded floribundane A (1), 4,5-dihydroblumenol A (5) ${ }^{7,8}$ and floribundane B (2).

*e-mail: disabel@ubi.pt

\section{Results and Discussion}

Floribundane A (1) was obtained as a colourless oil with $[\alpha]_{D}^{20}=+25.31^{\circ}$. The HR-TOF- EI-MS showed a molecular ion peak at $\mathrm{m} / z 223.0843[\mathrm{M}]^{+}$(in agreement with the molecular formula $\mathrm{C}_{11} \mathrm{H}_{13} \mathrm{NO}_{4}$ ) implying 6 degrees of unsaturation. The UV maximum at $234 \mathrm{~nm}$ and the IR absorptions at 1724,1633 and $1268 \mathrm{~cm}^{-1}$ suggested the presence of the chromophore $-\mathrm{OOCC}=\mathrm{CHO} .{ }^{9}$ The IR also showed the presence of a lactam ring: $\mathrm{NH}$ band $\left(3403 \mathrm{~cm}^{-1}\right)$, and the amide band I $\left(1690 \mathrm{~cm}^{-1}\right)$ with an absence of the amide II band. ${ }^{10}$ The ${ }^{1} \mathrm{H}$ NMR spectrum of compound (1) (Table 1) displayed signals of two vinylic protons $\left(\mathrm{H}-3 \delta_{\mathrm{H}} 7.50, \mathrm{~s}\right.$ and $\left.\mathrm{H}-8 \delta_{\mathrm{H}} 6.85, \mathrm{q}, J 7.2\right)$, a ABX system [H-6 $\alpha, \beta \delta_{\mathrm{H}} 2.11$, dd, $J 13.1$ and $2.0 ; \delta_{\mathrm{H}} 2.06$, dd, $J 13.1$ and 2.6 (AB part) and $\mathrm{H}-5 \delta_{\mathrm{H}} 3.94$, $\mathrm{m}$ (X part)] and a vinyl methyl group at $\delta_{\mathrm{H}} 2.01(\mathrm{~d}, J$ 7.2); typical signals of a secoiridoid nucleus. ${ }^{11}$ A few iridoid alkaloids have been isolated from natural sorces ${ }^{12-15}$ (gardenamide class), and some were obtained as metabolites produced by human ${ }^{16}$ and rat intestinal bacteria. ${ }^{17}$ Comparison with the published data of known iridoid alkaloids, such as (6) (Figure 1), and hemiacetal-secoiridoids ${ }^{11,18}$ like (7) (Figure 1) and compound (1), showed that the H-3 chemical shift $\left(\delta_{\mathrm{H}} 7.50 \mathrm{ppm}\right)$, despite the presence of a nitrogen atom in 
the molecule, was more compatible with the hemiacetalsecoiridoids $\left(\delta_{\mathrm{H}} c a .7 .5 \mathrm{ppm}\right)$ than with the gardenamide class and mor- $1^{17}(\mathbf{8})$ (Figure 1) $\left(\delta_{\mathrm{H}} c a .7 .3 \mathrm{ppm}\right)$. Further, the upfield shift of $\mathrm{H}-1\left(\delta_{\mathrm{H}} 5.46\right)$ relative to the corresponding signal of mor- $1\left(\delta_{\mathrm{H}} 5.11 \mathrm{ppm}\right),{ }^{17}$ and a downfield shift $\left(\delta_{\mathrm{H}} 5.94 \mathrm{ppm}\right)$ to the corresponding hemicetals, ${ }^{11,18}$ showed that (1) it was neither a hemiacetal nor a nitrogen-containing iridoid $(\mathrm{N}-2)$ but that it was compatible with a $\mathrm{C}-1(\mathrm{~N}) \mathrm{O}-2$ substitution. This was also supported by the presence of the ${ }^{1} \mathrm{H}-{ }^{1} \mathrm{H}$ COSY correlation between $\mathrm{H}-1 / \mathrm{NH}$, rather than the $\mathrm{H}-1 / \mathrm{NH}$, $\mathrm{H}-3 / \mathrm{NH}$ correlations expected in the iridoid alkaloids, ${ }^{17}$ and by UV and IR data indicating the presence of the chromophore $-\mathrm{OOCC}=\mathrm{CHO} .{ }^{9}$ The ${ }^{13} \mathrm{C}$ NMR spectrum (Table 1) showed 11 carbons which were analysed as two methyls (one vinylic and a methyl ester), one methylene, four methines two of them vinylic, and four quaternary carbons (two vinylic and two carbonylic) from its DEPT spectrum. The ${ }^{13} \mathrm{C}$ NMR chemical signals at $\delta_{\mathrm{C}} 152.13$ (C-3), 136.11 (C-8), 130.25 (C-9), the carbonyl group at $\delta_{\mathrm{C}} 166.56$, the methoxy signal at $\delta_{\mathrm{C}} 51.31$ and the vinyl methyl group at $\delta_{\mathrm{C}} 13.96$, were found to be consistent with a secoiridoid skeleton. ${ }^{11}$ The unusual downfield shift of $\mathrm{C}-1$ to $\delta_{\mathrm{C}} 76.97$ was in agreement with the $\mathrm{C}-1(\mathrm{O})$ (N) substitution as observed on mor- $1,{ }^{17}$ but only the presence of $\mathrm{O}$ in the position 2 of the iridoid skeleton could explain the upfield shift of C-3 and C-4. The HMBC correlation between $\mathrm{H}-1 / \mathrm{C}-7$ established the presence of the 1,7- $\delta$-lactam ring in the molecule. With the aid of ${ }^{1} \mathrm{H}-{ }^{1} \mathrm{H}$ COSY, HSQC and HMBC data (Table 1,
Figure 2) it was possible to establish the structure of (1) as a 7,8-secoiridoid, with $\mathrm{C}-11$ as a methyl ester, a C-1(N) O-2 substitution and a 1,7- $\delta$-lactam ring. The NOESY correlations $\mathrm{H}_{\alpha}-5 / \mathrm{H}_{\alpha}-6$ and $\mathrm{H}_{\beta}-6 / \mathrm{H}_{\beta}-1$ indicated that the $1,7-\delta$-lactam ring is trans-fused. To our best knowledge, this is the first time that a secoiridoid has presented as a 1,7-trans- $\delta$-lactam ring. A similar structure, isosweroside, as a hemiacetal, was found in the roots of Sambucus ebulus L. ${ }^{19}$ Compound (1) was named floribundane A.

Floribundane B (2) was obtained as a colourless oil with $[\alpha]_{D}^{20}=+41.66^{\circ}$. The molecular formula $\mathrm{C}_{9} \mathrm{H}_{14} \mathrm{O}_{3}$ was established by HR-TOF-MS-EI which showed a molecular ion peak at $\mathrm{m} / \mathrm{z} 170.0942[\mathrm{M}]^{+}$(calculated for 170.2270), implying 3 degrees of unsaturation. The IR showed $\mathrm{OH}$ bands $\left(3384 \mathrm{~cm}^{-1}\right)$, an $\alpha, \beta$-unsaturated lactone group $\left(1692 \mathrm{~cm}^{-1}, 1620 \mathrm{~cm}^{-1}\right)$; the UV spectrum a $\alpha, \beta$-unsaturated lactone system $(230 \mathrm{~nm})$. The ${ }^{1} \mathrm{H}$ RMN spectrum (Table 1) showed signals of one diastereotopic oxymethylene (H-3) $\delta_{\mathrm{H}} 4.23\left(\mathrm{ddd}, J_{1} 11.3, J_{2} 9.1, J_{3} 4.4 \mathrm{~Hz}\right)$ and $\delta_{\mathrm{H}} 4.42(\mathrm{ddd}$, $\left.J_{1} 11.3, J_{2} 9.5, J_{3} 3.6 \mathrm{~Hz}\right)$ that presented ${ }^{1} \mathrm{H}-{ }^{1} \mathrm{H}$ COSY correlation with a diastereotopic methylene $(\mathrm{H}-4) \delta_{\mathrm{H}} 1.83$ (m) and $\delta_{\mathrm{H}} 2.12(\mathrm{~m})$; a oxymethylene multiplet $\delta_{\mathrm{H}} 3.71$ (H-7) that presented an ${ }^{1} \mathrm{H}-{ }^{1} \mathrm{H}$ COSY correlation with another methylene $\delta_{\mathrm{H}} 1.74(\mathrm{~m}, \mathrm{H}-6)$; a methine $\delta_{\mathrm{H}} 3.18$ (m, H-5) that showed cross peaks with $\mathrm{H}-4$ and $\mathrm{H}-6$ and a vinyl methine $\delta_{\mathrm{H}} 7.02$ (qd, $\left.J_{1} 7.4, J_{2} 1.2 \mathrm{~Hz}, \mathrm{H}-8\right)$ coupled with a methyl $\delta_{\mathrm{H}} 1.86(\mathrm{~d}, J 7.4 \mathrm{~Hz}, \mathrm{Me}-10)$. This spectrum presents some similarities to that of compound (1): the presence of the vinyl double bond and the ${ }^{1} \mathrm{H}-{ }^{1} \mathrm{H}$ COSY correlations between H-5, H-6 and H-7. Thus, it appears

Table 1. ${ }^{1} \mathrm{H}$ NMR and ${ }^{13} \mathrm{C}$ NMR data $(J$ in $\mathrm{Hz})$ and $\mathrm{HMBC}$ correlations of compounds 1 and $2\left(600 \mathrm{MHz} \mathrm{CDCl}_{3}\right)$

\begin{tabular}{|c|c|c|c|c|c|c|c|c|}
\hline \multirow{2}{*}{$\mathrm{C}$} & \multicolumn{4}{|c|}{1} & \multicolumn{4}{|c|}{2} \\
\hline & $\delta_{\mathrm{C}}$ & $\delta_{\mathrm{H}}$ & COSY & $\mathrm{HMBC}$ & $\delta_{\mathrm{C}}$ & $\delta_{\mathrm{H}}$ & COSY & HMBC \\
\hline 1 & 76.97 & 5.46, br s & $\mathrm{H}-5, \mathrm{NH}$ & $3,5,7$ & 167.38 & & & \\
\hline 3 & 152.13 & $7.50, \mathrm{~s}$ & & $1,4,5,11$ & 65.35 & $\begin{array}{l}4.23 \text {, ddd }(11.3,9.1,4.4) \mathrm{a} \\
4.42 \text {, ddd }(11.3,9.5,3.6) \mathrm{b}\end{array}$ & $\begin{array}{c}\mathrm{H}-3, \mathrm{H}-4 \mathrm{a} \\
\mathrm{H}-4 \mathrm{~b}\end{array}$ & $1,4,5$ \\
\hline 4 & 109.36 & & & & 27.51 & $\begin{array}{l}1.83, \mathrm{~m} \mathrm{a} \\
2.12, \mathrm{~m} \mathrm{~b}\end{array}$ & $\begin{array}{c}\text { H-3a, H-3b, } \\
\text { H-4a, H-4b, H-5 }\end{array}$ & $3,5,6,9$ \\
\hline 5 & 24.67 & $3.94, \mathrm{~m}$ & H-1, H-6 & $1,3,4,6,7,8,9$ & 28.93 & $3.18, \mathrm{~m}$ & $\begin{array}{c}\text { H4a, H-4b, } \\
\text { H-5, H-6 }\end{array}$ & $1,3,4,6,8,9$ \\
\hline 6 & 26.76 & $\begin{array}{l}2.06, \text { dd }(13.1,2.6) \\
2.11, \text { dd }(13.1,2.0)\end{array}$ & H-5, H-6 & $4,5,9$ & 36.11 & $1.74, \mathrm{~m}$ & $\mathrm{H}-5, \mathrm{H}-7$ & $4,5,9$ \\
\hline 7 & 166.36 & & & & 59.97 & $3.71, \mathrm{~m}$ & H-6 & 5,6 \\
\hline 8 & 136.11 & $6.85, \mathrm{q}(7.2)$ & $\mathrm{H}-10$ & $5,9,10$ & 140.67 & $7.02, \mathrm{qd}(7.4,1.2)$ & H-5, H-10 & $1,5,9,10$ \\
\hline 9 & 130.25 & & & & 131.16 & & & \\
\hline 10 & 13.96 & $2.01, \mathrm{~d}(7.2)$ & H-8 & 8,9 & 14.18 & $1.86, \mathrm{~d}(7.4)$ & H-8 & 8,9 \\
\hline 11 & 166.56 & & & & & & & \\
\hline $11-\mathrm{OCH}_{3}$ & 51.31 & $3.69, \mathrm{~s}$ & & 11 & & & & \\
\hline $\mathrm{NH}$ & - & 6.93 , br s & H-1 & & & & & \\
\hline
\end{tabular}



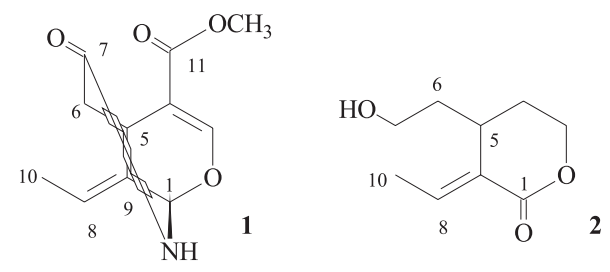<smiles>C=C(C)C1CCC2(C)CCC3C(CCC4C3(C)CCC3C(C)(C)C(=O)CCC34C)C12</smiles><smiles>COc1cc2ccc(=O)oc2cc1O</smiles><smiles>C[C@H](O)/C=C/[C@@]1(O)[C@@H](C)CC(=O)CC1(C)C</smiles><smiles>CC(=O)C1=CNC(=O)C2C(CO)=CCC12</smiles><smiles>C/C=C1/C(OC)OC=C(C(C)=O)C1CC(=O)O</smiles>
6<smiles>CC(=O)C1=CNC2OC3CC4CC12C4O3</smiles>

8

Figure 1. Structures of selected examples of iridoid alkaloids ${ }^{13}(\mathbf{6})$, hemiacetal-secoiridoids ${ }^{11}(7)$ and mor-1 (8) ${ }^{17}$

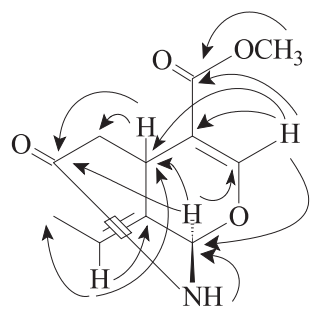

1

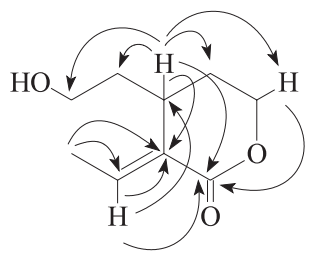

2
Figure 2. Key HMBC correlations of compounds $\mathbf{1}$ and $\mathbf{2}$.

that the A ring, as in (1), is open as a 7,8-secoiridoid with a hydroxyl moiety at C-7. The ${ }^{13} \mathrm{C}$ NMR spectrum (Table 1) showed 9 carbons which were analysed, from its DEPT spectrum, as one vinylic methyl $\left(\delta_{\mathrm{C}} 14.18\right)$, four methylenes (two of them oxymethylenes, $\delta_{\mathrm{C}} 27.51,36.11$, $59.97,65.35$ ), two methines (one vinylic, $\delta_{\mathrm{C}} 28.93,140.67$ ), and two quaternary carbons (one vinilyc, $\delta_{\mathrm{C}} 131.16$, and the other carbonylic, $\delta_{\mathrm{C}}$ 167.38). The lack of the two quaternary $\mathrm{sp}^{2}$ carbons belonging to the C-3 - C-4 double bond of (1) and the methine $\mathrm{C}-1$, and the presence of signals characteristic of a methylene $\left(\delta_{\mathrm{C}} 27.51\right)$, a oxymethylene $\left(\delta_{\mathrm{C}} 65.35\right)$ and a sp ${ }^{2}$ carbon $\left(\delta_{\mathrm{C}} 167.38\right)$ belonging to the $\alpha, \beta$-unsaturated lactone group detected in the IR and UV spectra, is indicative of a major transformation in the $\mathrm{B}$ ring of (2). However, these new features of the B ring are in good agreement with those of the $\delta$-lactone ring of C-9 iridoid derivatives viteoid II, ${ }^{20,21}$ 7-hidroxyviteoid $\mathrm{II}^{22}$ and ovatolactone. ${ }^{23}$ The vinylic double bond can unambiguously be assigned to C-8 and C-9 and the lactone carbonyl to C-1, by means of ${ }^{1} \mathrm{H}-{ }^{1} \mathrm{H}$ COSY, HSQC and HMBC data (Table 1, Figure 2). Several C-9 iridoid and secoiridoid (lactone ring opening) derivatives are known ${ }^{20-25}$ but to our best knowledge this is the first time that a C-9 7,8-secoiridoid derivative has been isolated. Thus, (2) was identified as a new natural product for which we propose the name floribundane $\mathrm{B}$.

\section{Conclusions}

Although trunk bark components of $H$. floribundum have been well studied, there has as yet been no study which focuses solely on the leaves of this medicinal tree. The major compound trunk bark extract is scopoletin. The occurrence of iridoids has been observed for the first time in this genus. A new secoiridoid alkaloid, floribundane A, and a C-9 7,8-secoiridoid, floribundane B was isolated from the leaves of this tree.

\section{Experimental}

\section{General experimental procedures}

Optical rotations were obtained with a Bellingham+Stanley Ltd ADP 220 polarimeter. HREIMS measurements were carried out on a VG Autospec M and recorded at $70 \mathrm{eV}$. FTIR and UV spectra were measured in a Unicam Mattson 5000 FTIR and Unican He $\lambda$ ios $\alpha$ respectively. NMR spectra were recorded in a Bruker Avance II, $600 \mathrm{MHz}\left({ }^{1} \mathrm{H}\right.$ NMR) and $150.9 \mathrm{MHz}$ $\left({ }^{13} \mathrm{C}\right.$ NMR), in $\mathrm{CDCl}_{3}$. Chemical shifts are given in $\delta \mathrm{ppm}$ and are referenced to the residual $\mathrm{CHCl}_{3}, 7.26 \mathrm{ppm}$ for the ${ }^{1} \mathrm{H}$ and $77.0 \mathrm{ppm}$ for ${ }^{13} \mathrm{C}$. Two-dimensional experiments were performed with standard Bruker software. Column chromatography was carried out on silica gel (silica gel 60 (70-230 mesh), Merck, Darmstadt, Germany). 


\section{Plant material}

Leaves and bark of Hymenodictyon floribundum were collected in the waterfall at the Comuna da Huíla, Huíla province, Angola in July 2001. A voucher specimen (3668) has been deposit at the Lubango Herbarium, Angola.

\section{Extraction and isolation}

Powdered trunk bark ( $3 \mathrm{~kg}$ ) was extracted with methanol for a week at room temperature. The methanol extract was partitioned between $\mathrm{MeOH}-\mathrm{H}_{2} \mathrm{O}$ (5:1) and hexane yielding $16.6 \mathrm{~g}$ of the hexane extract. The aq. methanolic fraction was concentrated, $\mathrm{H}_{2} \mathrm{O}$ added and extracted with chloroform to obtain the chloroform extract ( $36.8 \mathrm{~g}$ ). A sample of the hexane extract $(4.7 \mathrm{~g})$ was fractionated in silica gel column with a hexane/EtOAc, EtOAc and EtOAc/MeOH gradients. The fraction eluted with hexane/EtOAc (95:5) was separated in silica gel column with a hexane/EtOAc gradient to yield lupenone (3) (20.3 mg). From the chloroform extract and by crystallization scopoletin (4) (30 g) was isolated.

Dried leaves $(0.9 \mathrm{~kg})$ were extracted with methanol for a week at room temperature. The methanol extract was partitioned between $\mathrm{MeOH}-\mathrm{H}_{2} \mathrm{O}(5: 1)$ and hexane yielding $34.02 \mathrm{~g}$ of the hexane extract. The aq. methanolic fraction was concentrated, $\mathrm{H}_{2} \mathrm{O}$ added and extracted with chloroform to obtain the chloroform extract $(5.2 \mathrm{~g})$. A sample of the chloroform extract $(1.6 \mathrm{~g})$ was fractionated in silica gel column with a hexane/EtOAc, EtOAc/ $\mathrm{CHCl}_{3}$ and $\mathrm{EtOAc} / \mathrm{MeOH}$ gradients. Two fractions were eluted with EtOAc/ $\mathrm{CHCl}_{3}$ (7:3) (fraction I and II). Fraction I was separated in silica gel column with $\mathrm{CHCl}_{3}$ and a $\mathrm{CHCl}_{3}$ I $\mathrm{MeOH}$ gradient to yield floribundane A (1) $(10.2 \mathrm{mg})$ and 4,5-dihydroblumenol A (5) (5.6 mg). Fraction II was separated in silica gel column with $\mathrm{CHCl}_{3}$ and a $\mathrm{CHCl}_{3}$ / $\mathrm{MeOH}$ gradient to yield floribundane $\mathrm{B}(2)(7.8 \mathrm{mg})$.

\section{Floribundane A (1)}

Oil; $[\alpha]_{D}^{20}=+25.31^{\circ}\left(\mathrm{CHCl}_{3}, c\right.$ 0.079). FTIR (film) $v_{\max } / \mathrm{cm}^{-1}: 3403,2959,2930,1724,1690,1633,1379$, 1268, 1196, 1092, 943, 756; UV (MeOH) $\lambda_{\text {max }} / \mathrm{nm}(\log \varepsilon)$ : 234 (4.00), 210.0 (4.15) ${ }^{1} \mathrm{H} \mathrm{NMR}\left(\mathrm{CDCl}_{3}, 600 \mathrm{MHz}\right)$ and ${ }^{13} \mathrm{C}$ NMR $\left(\mathrm{CDCl}_{3}, 150.9 \mathrm{MHz}\right)$ : see Table 1; TOF-MS-EI pos: $m / z 223[\mathrm{M}]^{+}(15), 206$ (77), 190 (100), 164 (62), 163 (12), 162 (11), 149 (28), 146 (22), 134 (11), 122 (23), 121 (82), 120 (13), 93 (13), 83 (13), 79 (10); HREIMS: $\mathrm{m} / \mathrm{z}$ $223.0843[\mathrm{M}]^{+}$(calc. for $\mathrm{C}_{11} \mathrm{H}_{13} \mathrm{NO}_{4}, 223.0845$ ).

\section{Floribundane B (2)}

Oil; $[\alpha]_{D}^{20}=+41.66^{\circ}\left(\mathrm{CHCl}_{3}, c\right.$ 0.048). FTIR (film) $v_{\max } / \mathrm{cm}^{-1}: 3384,2962,2926,2866,1692,1620,1262,1154$,
1094, 1060, 1026, 800, 760; UV (MeOH) $\lambda_{\text {max }} / \mathrm{nm}(\log \varepsilon)$ : 230 (3.16), 219 (3.34). ${ }^{1} \mathrm{H}$ NMR $\left(\mathrm{CDCl}_{3}, 600 \mathrm{MHz}\right)$ and ${ }^{13} \mathrm{C}$ NMR $\left(\mathrm{CDCl}_{3}, 150.9 \mathrm{MHz}\right)$ see Table 1 ; TOF-MS-EI pos: $m / z 226[\mathrm{M}]^{+}$(1), 168 (25), 137 (11), 135 (12), 128 (19), 126 (39), 125 (31), 124 (34), 123 (38), 122 (11), 121 (24), 111 (100), 110 (29), 109 (73), 108 (12), 107 (22), 99 (15), 98 (17), 97 (33), 96 (17), 95 (72), 93 (17), 91 (14), 85 (81), 84 (11), 83 (11), 83 (32), 82 (19), 81 (40), 79 (17), 77 (12), 71 (39), 69 (46), 67 (20); HREIMS: m/z 170.0942 $[\mathrm{M}]^{+}$(calc. for $\mathrm{C}_{9} \mathrm{H}_{14} \mathrm{O}_{3}, 170.2270$ ).

\section{Supplementary Information}

${ }^{1} \mathrm{H}$ NMR, ${ }^{13} \mathrm{C}$ NMR, ${ }^{1} \mathrm{H}-{ }^{-1} \mathrm{H}$ COSY, HSQC, HMBC, and NOESY NMR spectra of compounds $\mathbf{1}$ and $\mathbf{2}$ are available free of charge at http://jbcs.sbq.org.br, as PDF file.

\section{Acknowledgments}

This work was partially funded by the project POCTI/ QUI/39380/2001 of Fundação para a Ciência e Tecnologia (FCT) with FEDER funding and Textile and Paper Materials Center. One of the authors (C.B.) gratefully acknowledges a GRICES PhD scholarship and INABE (Angola) for financial support.

\section{References}

1. Razafimandimbison, S. G.; Bremer, B.; Bot. J. Linn. Soc. 2006, 152, 331 .

2. Bossard, E.; Medicine Traditionnelle au Centre et a l'Ouest de l'Angola, Vol. 1, Ministério da Ciência e Tecnologia, Instituto de Investigação Científica Tropical: Lisbon, 1996.

3. Mitaine-Offer, A. C.; Tapondjou, L. A.; Djoukeng, J. D.; Bouda, H.; Lacaille-Dubois, M. A.; Biochem. Syst. Ecol. 2003, 31, 227.

4. dos Santos, A. F.; Lopes, L. A.; Mata, R. C. S.; de Mendonça, D. I. M. D.; Sant'Ana, A. E. G.; Bioresour. Technol. 2007, 98, 135.

5. Atta-Ur-Rahman; Pentacyclic Triterpenoids, Vol II, Elsevier Science B.V.: Amsterdam, 1994.

6. Rao, P. S.; Asheervadam, Y; Khaleelullah, M.; Rao, N. S.; Murray, R. D. H.; J. Nat. Prod. 1988, 51, 959.

7. de Marino, S.; Borbone, N.; Zollo, N.; Ianaro, A.; Di Meglio, P.; Iorizzi, M; J. Agric. Food Chem. 2004, 52, 7525.

8. Gonzalez, A. G.; Guillermo, J. A.; Ravelo, A. G.; Jiménez, I. A.; Gupta, M. P.; J. Nat. Prod. 1994, 57, 400.

9. Zuleta, L. M. C.; Cavalheiro, A. J.; Silva, D. H. S.; Furlan, M.; Young, M. C. M.; Albuquerque, S.; Castro-Gamboa, I.; Bolzani, V. S.; Phytochemistry 2003, 64, 549.

10. Pretsch, E.; Seilb, J.; Simon, W.; Tablas para la Determinación Estrutural por Métodos Espectroscópicos, Springer-Verlag Ibérica:Madrid, 1998, p. I150. 
11. Shen, Y. C.; Lin, S. L.; Chein, C. C.; Phytochemistry 1996, 42, 1629.

12. Machida, K.; Onodera, R.; Furuta, K.; Kikuchi, M.; Chem. Pharm. Bull. 1998, 46, 1295.

13. Bringmann, G.; Hamm, A.; Kraus, J.; Ochse, M.; Noureldeen, A.; Jumbam, D. N.; Eur. J. Org. Chem. 2001, 1983.

14. Juma, B. F.; Majinda, R. R. T.; Nat. Prod. Res. 2007, 21, 121.

15. Ono, M.; Ishimatsu, N.; Masouka, C.; Yoshimitsu, H.; Tsuchihashi, R.; Okawa, M.; Kinjo, J.; Ikeda, T.; Nohara, T.; Chem. Pharm. Bull. 2007, 55, 632.

16. Kawata, Y.; Hattori, M.; Akao, T.; Kobashi, K.; Namba, T.; Planta Med. 1991, 57, 536.

17. Li, X.; Huo, C.; Wang, Q.; Zhang, X.; Sheng, X.; Zhang, L.; J. Pharm. Biomed. Anal. 2007, 45, 268.

18. Tanahashi, T.; Takenaka, Y.; Nagakura, N.; J. Nat. Prod. 1997, 60,514 .
19. Gross, G. A.; Sticher, O.; Helv. Chim. Acta 1986, 69, 1113.

20. Ono, M.; Ito, Y.; Kubo, S.; Nohara, T.; Chem. Pharm. Bull. 1997, 45, 1094.

21. dos Santos, T. C.; Schripsema, J.; Monache, F. D.; Leitão, S. G.; J. Braz. Chem. Soc. 2001, 12, 763.

22. Gouda, Y. G.; Abdel-baky, A. M.; Darwish, F. M.; Mohamed, K. M.; Kasai, R.; Yamasaki, K.; Phytochemistry 2003, 63, 887.

23. Machida, K.; Ando, M.; Yaoita, Y.; Kakuda, R.; Kikuchi, M.; Chem. Pharm. Bull. 2001, 49, 732.

24. Marini-Bettolo, G. B.; Nicoletti, M.; Messana, I.; Patamia, M.; Galeffi, G.; Oguakwa, J. U.; Portalone, G.; Vaciago, A.; Tetrahedron 1983, 39, 323.

25. Valladares, M. G.; Rios, M. Y.; J. Nat. Prod. 2007, 70, 100.

Received: February 25, 2009 Web Release Date: March 22, 2010 


\section{Iridoids from Hymenodictyon floribundum}

Cristina M. P. Borges, ${ }^{a}$ Carlos Diakanawma ${ }^{b}$ and Dina I. M. D. de Mendonça ${ }^{*, c}$

${ }^{a}$ Departamento de Química and ${ }^{b}$ Departamento de Biologia, Universidade Agostinho Neto, Av. 4 de Fevereiro, 71, $2^{\circ}$ andar, CP 3244, Luanda, Angola

'Departamento de Química, Universidade da Beira Interior, Rua Marquês d'Ávila e Bolama, 6200-001 Covilhã, Portugal

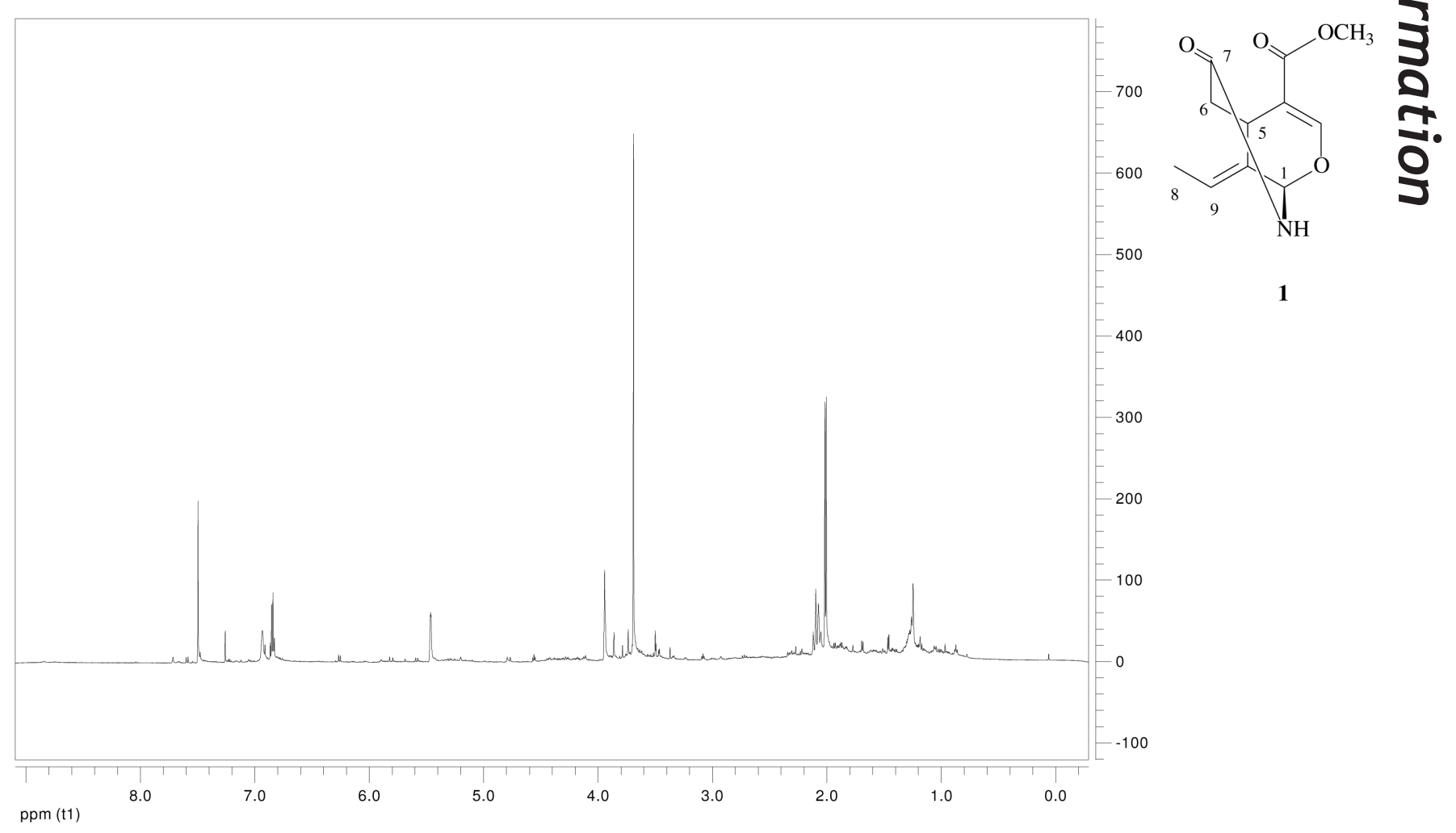

Figure S1. ${ }^{1} \mathrm{H}$ NMR spectrum $\left(600 \mathrm{MHz}, \mathrm{CDCl}_{3}\right)$ of compound (1). 


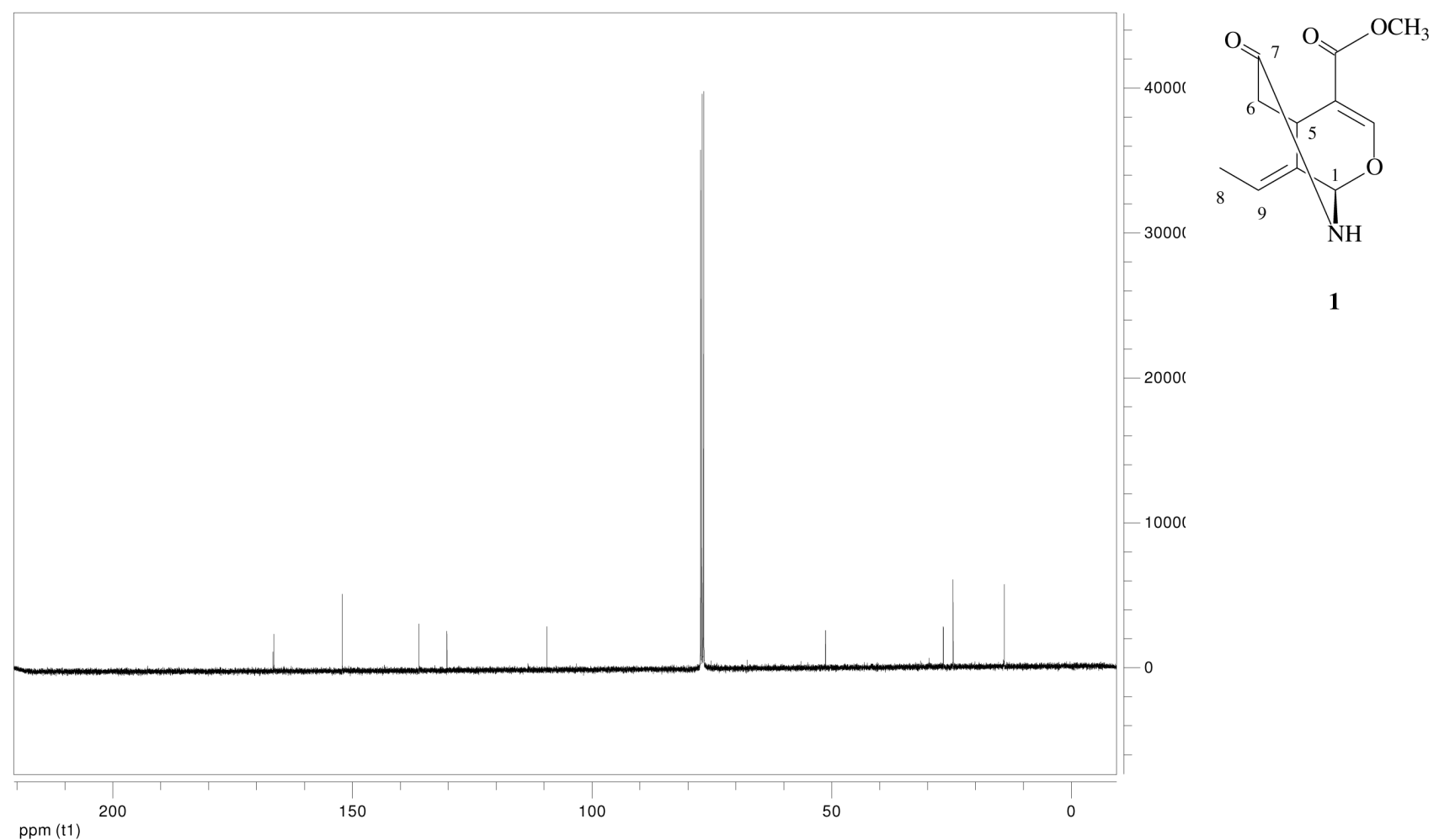

Figure S2. ${ }^{13} \mathrm{C}$ NMR spectrum $\left(150.9 \mathrm{MHz}, \mathrm{CDCl}_{3}\right)$ of compound (1).

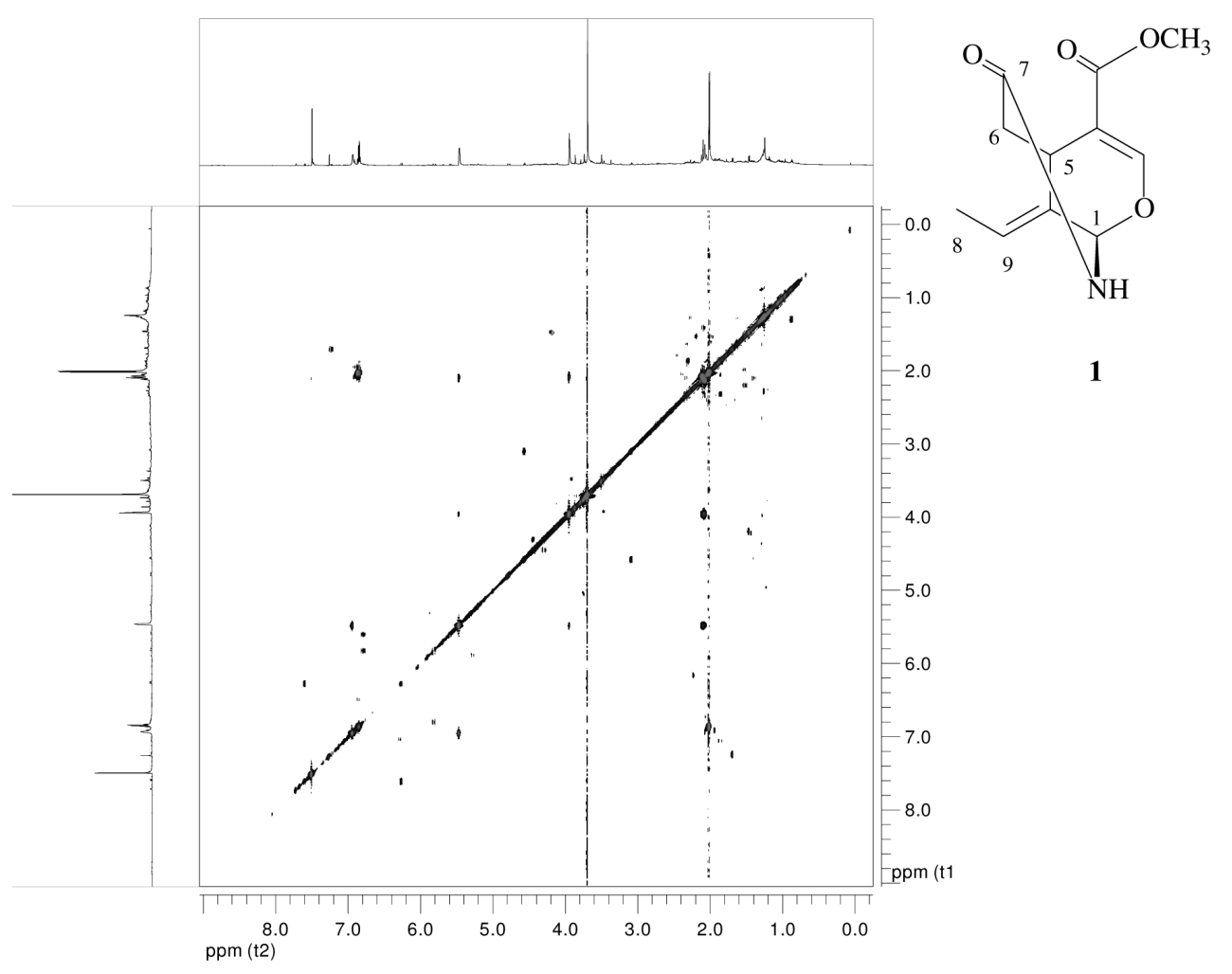

Figure S3. ${ }^{1} \mathrm{H}-{ }^{1} \mathrm{H}$ COSY spectrum $\left(600 \mathrm{MHz}, \mathrm{CDCl}_{3}\right)$ of compound (1). 


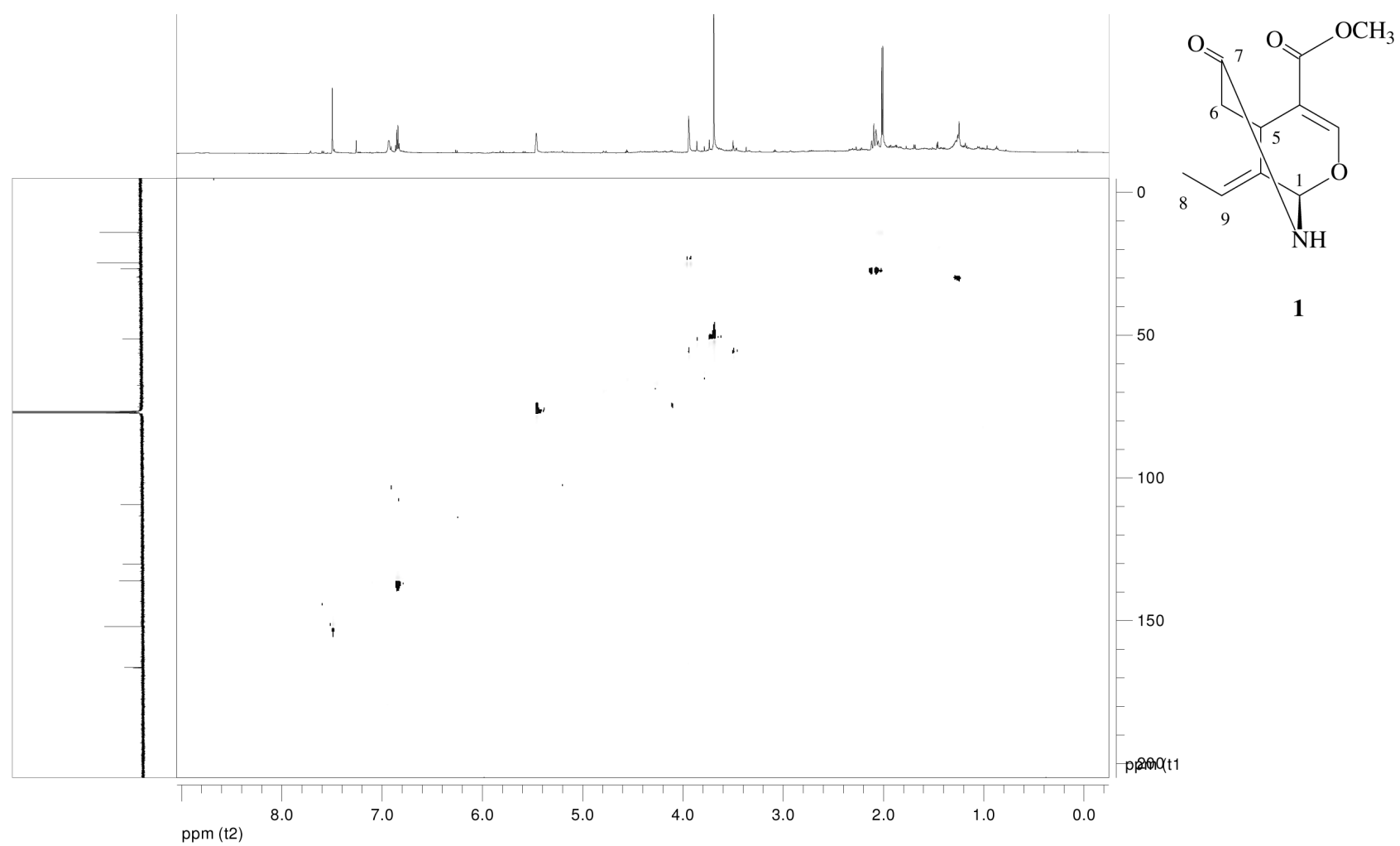

Figure S4. HSQC spectrum (150.9 MHz, $\mathrm{CDCl}_{3}$ ) of compound (1).

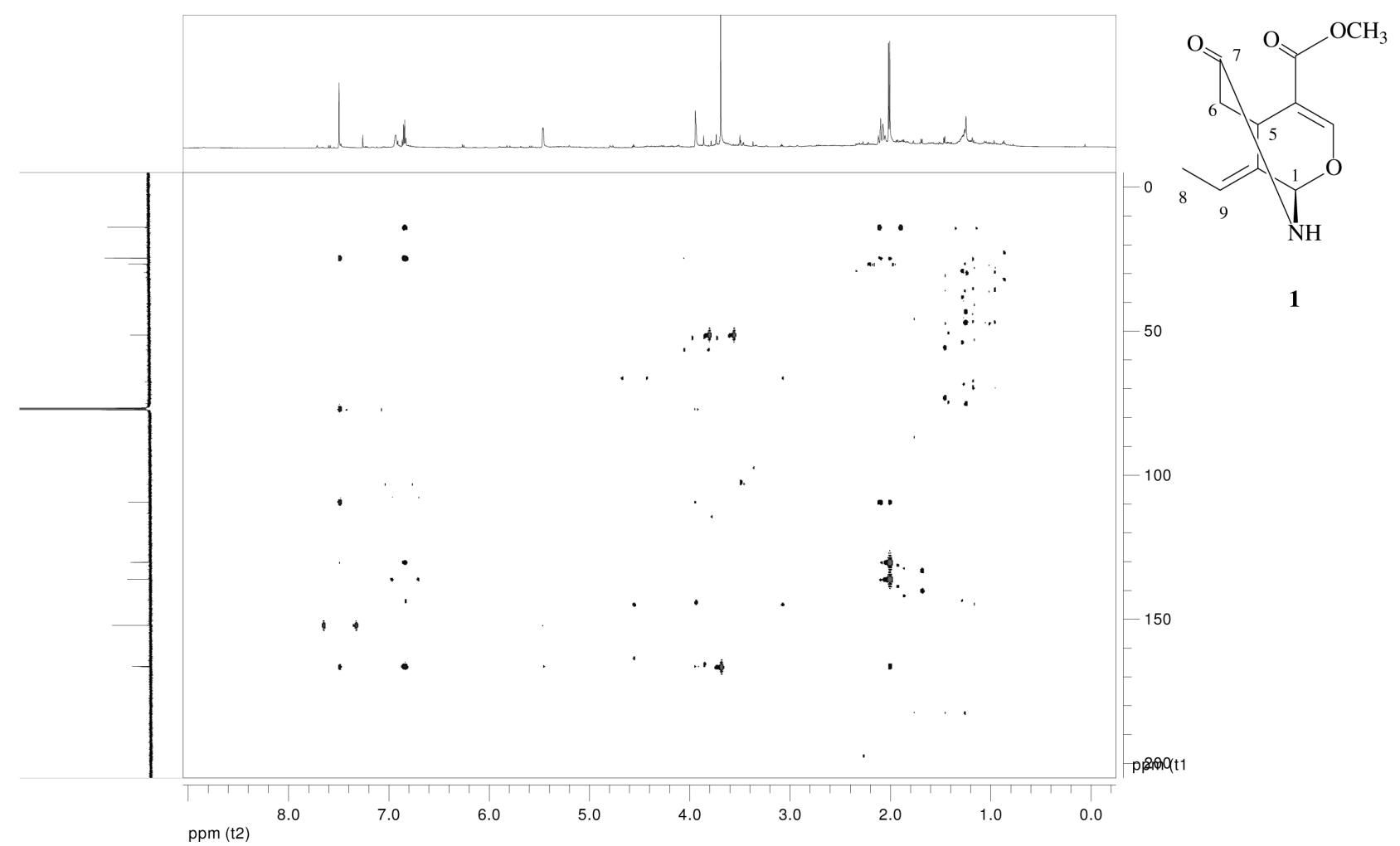

Figure S5. HMBC spectrum (150.9 MHz, $\mathrm{CDCl}_{3}$ ) of compound (1). 


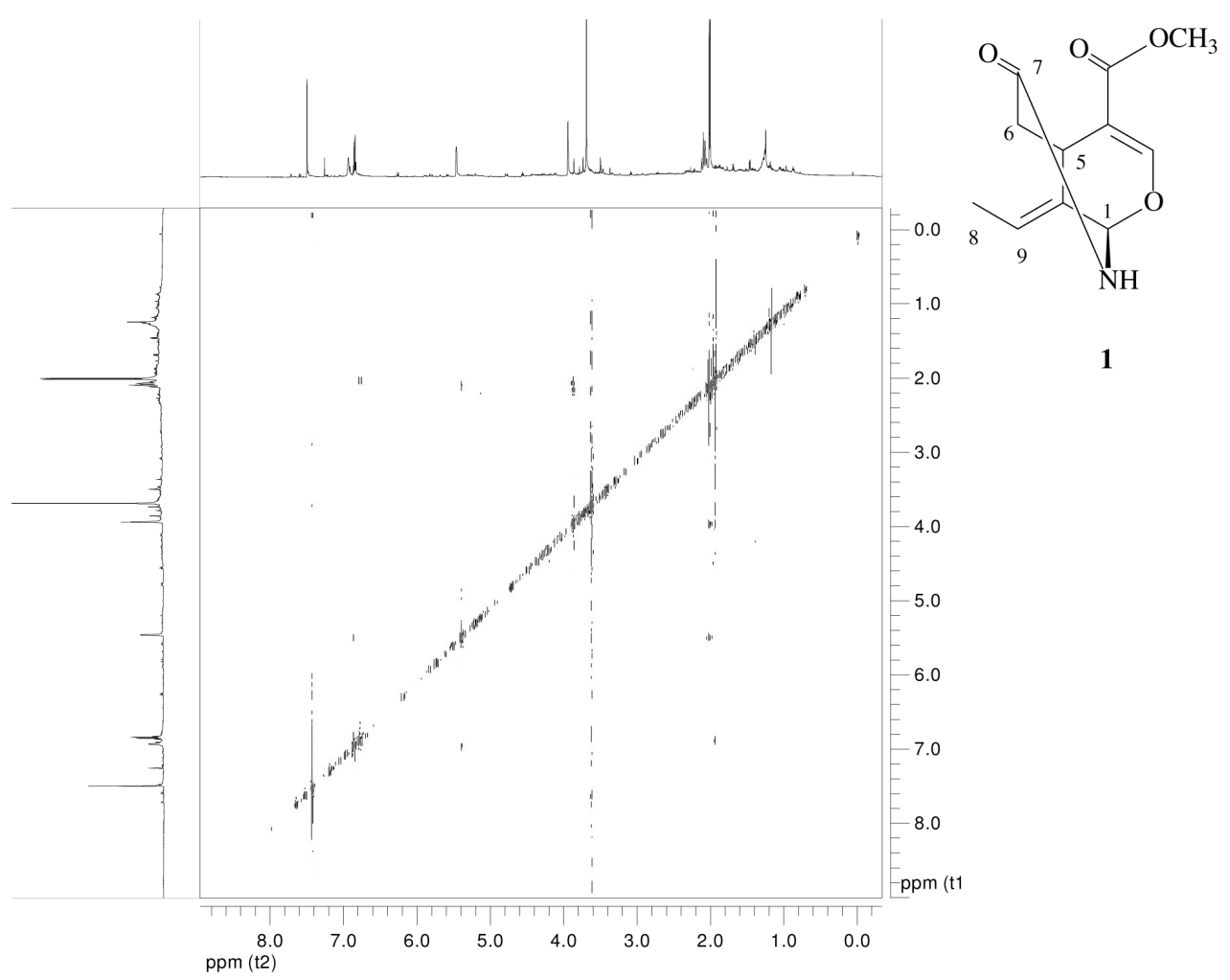

Figure S6. NOESY spectrum (600 MHz, $\mathrm{CDCl}_{3}$ ) of compound (1).

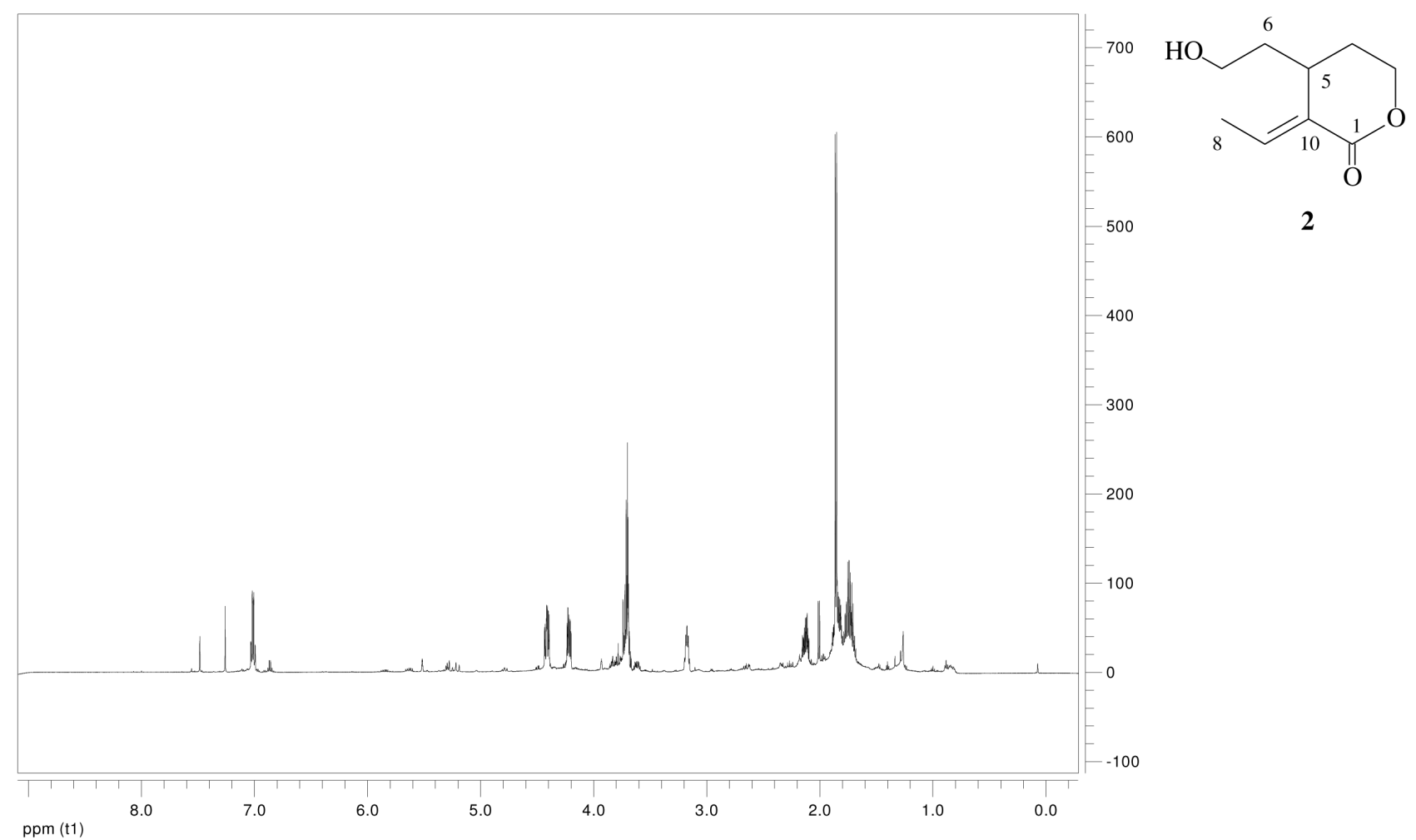

Figure S7. ${ }^{1} \mathrm{H}$ NMR spectrum (600 MHz, $\mathrm{CDCl}_{3}$ ) of compound (2). 


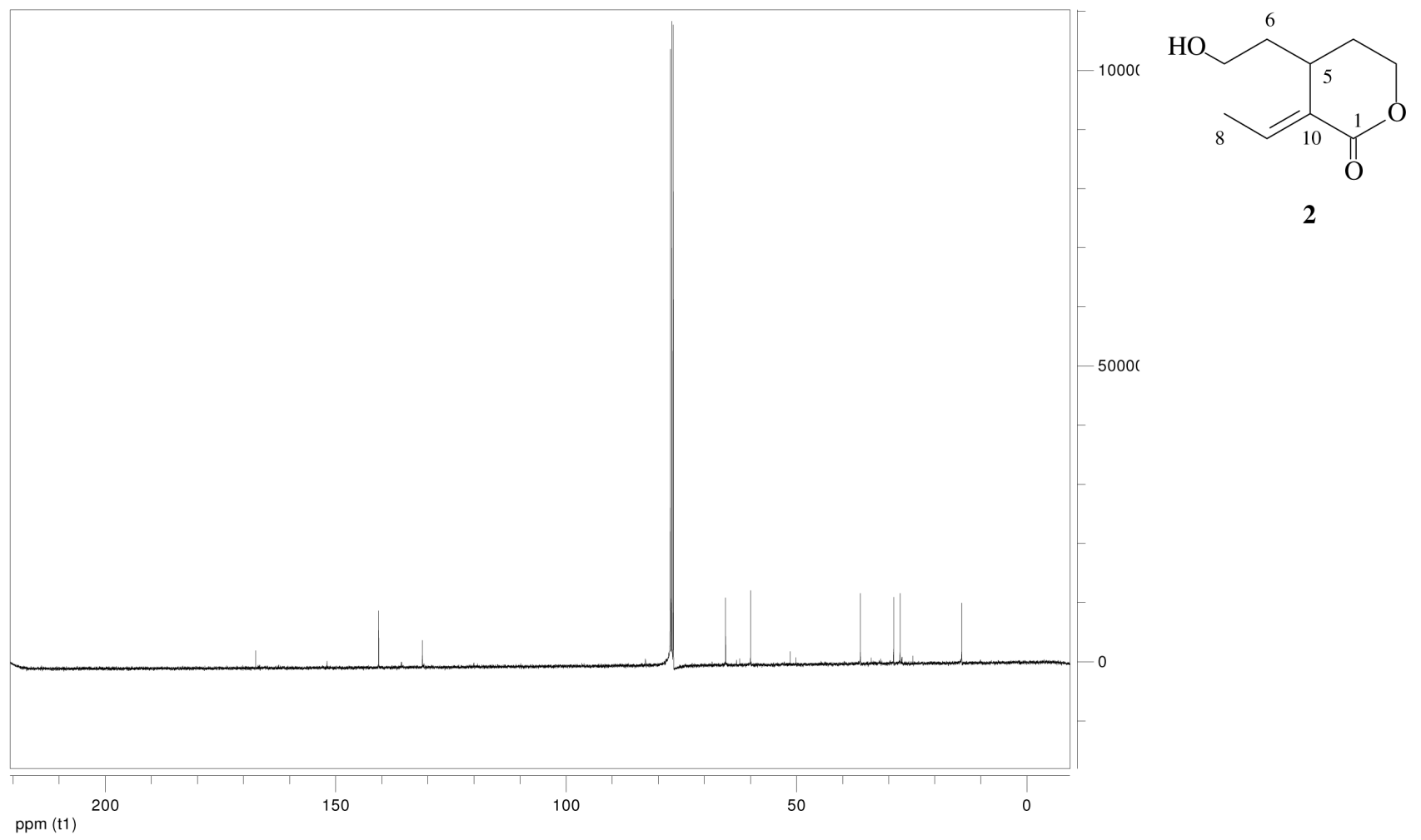

Figure S8. ${ }^{13} \mathrm{C}$ NMR spectrum (150.9 $\mathrm{MHz}, \mathrm{CDCl}_{3}$ ) of compound (2).

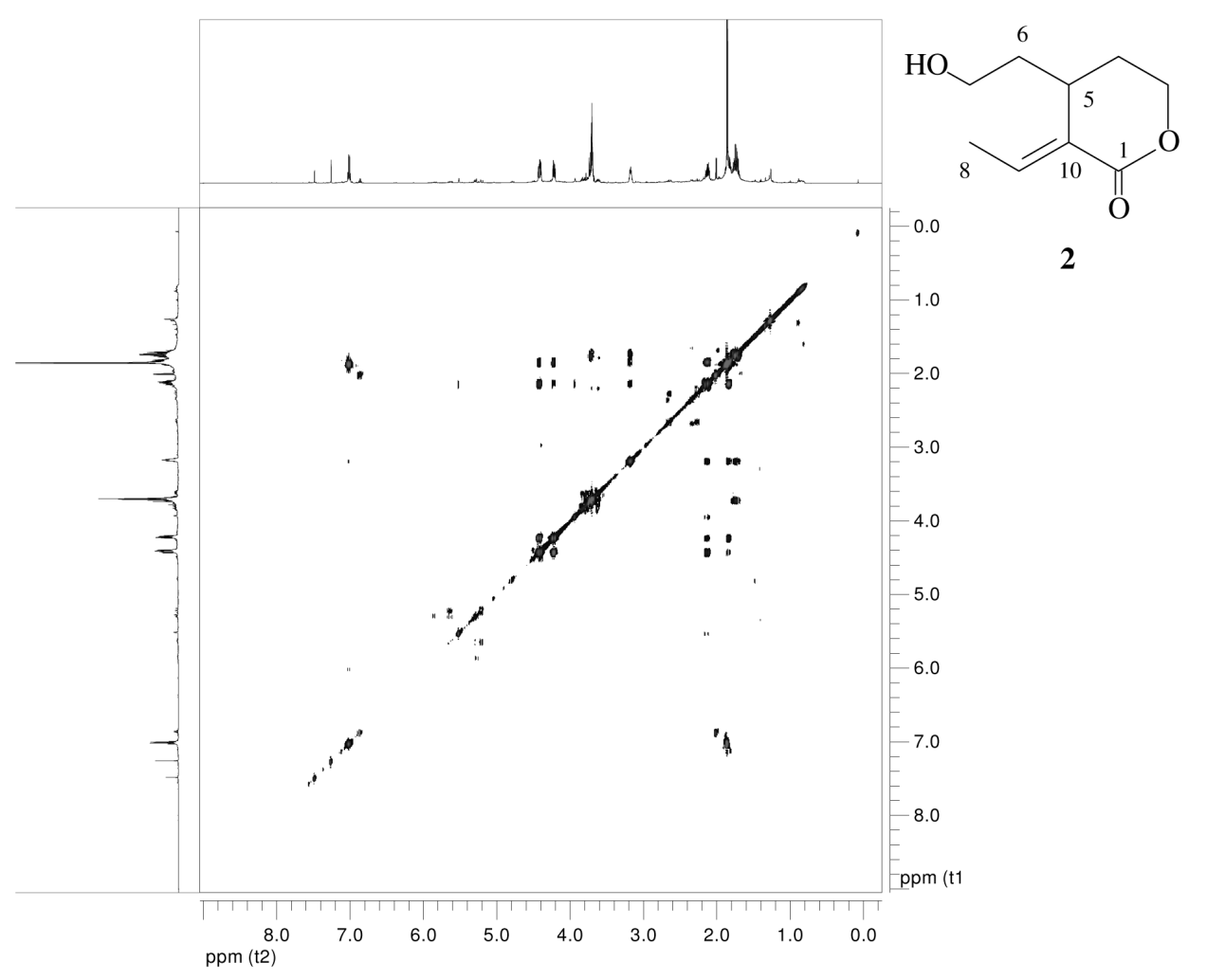

Figure S9. ${ }^{1} \mathrm{H}-{ }^{1} \mathrm{H}$ COSY spectrum $\left(600 \mathrm{MHz}, \mathrm{CDCl}_{3}\right)$ of compound (2). 


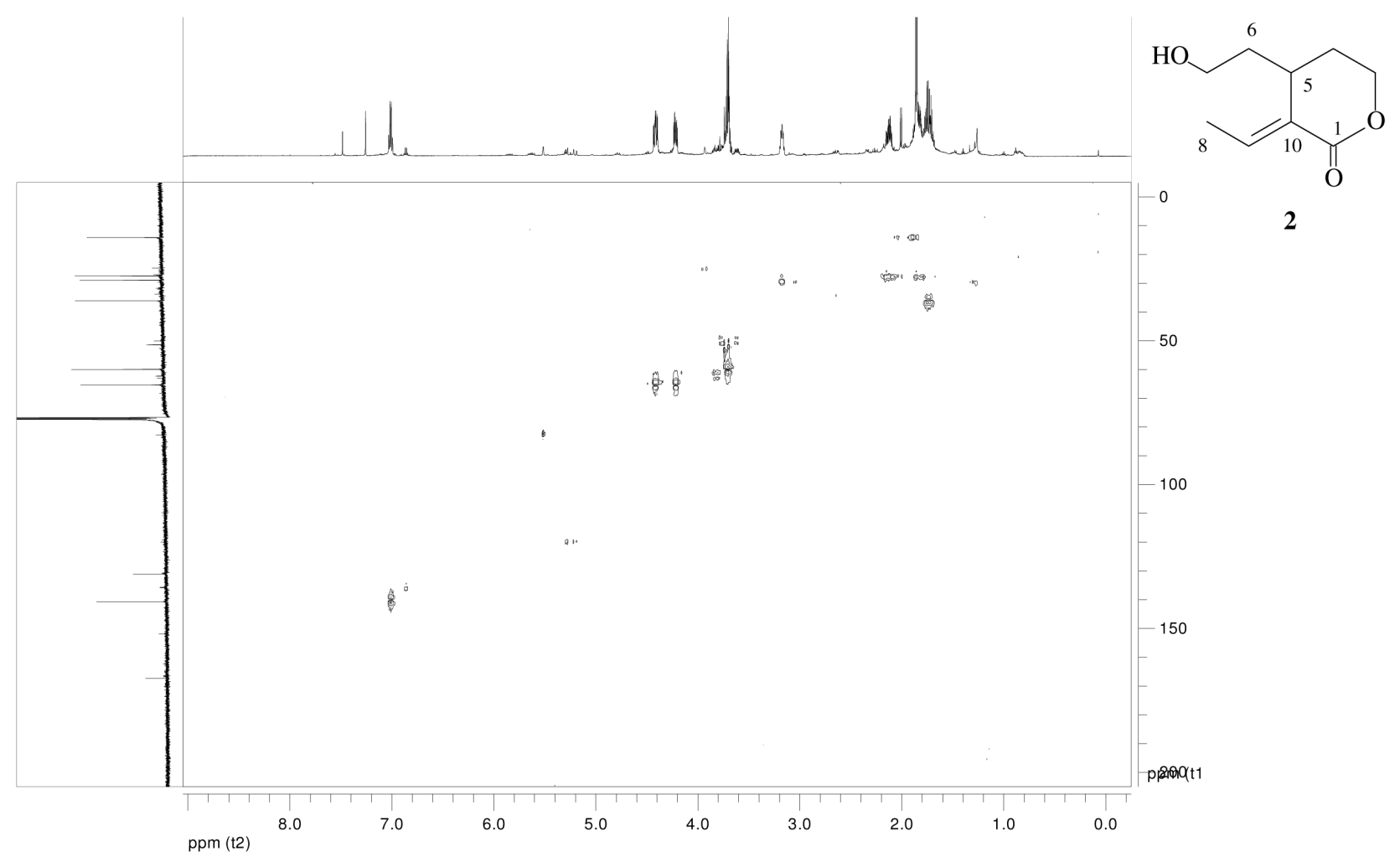

Figure S10. HSQC spectrum (150.9 MHz, $\mathrm{CDCl}_{3}$ ) of compound (2).

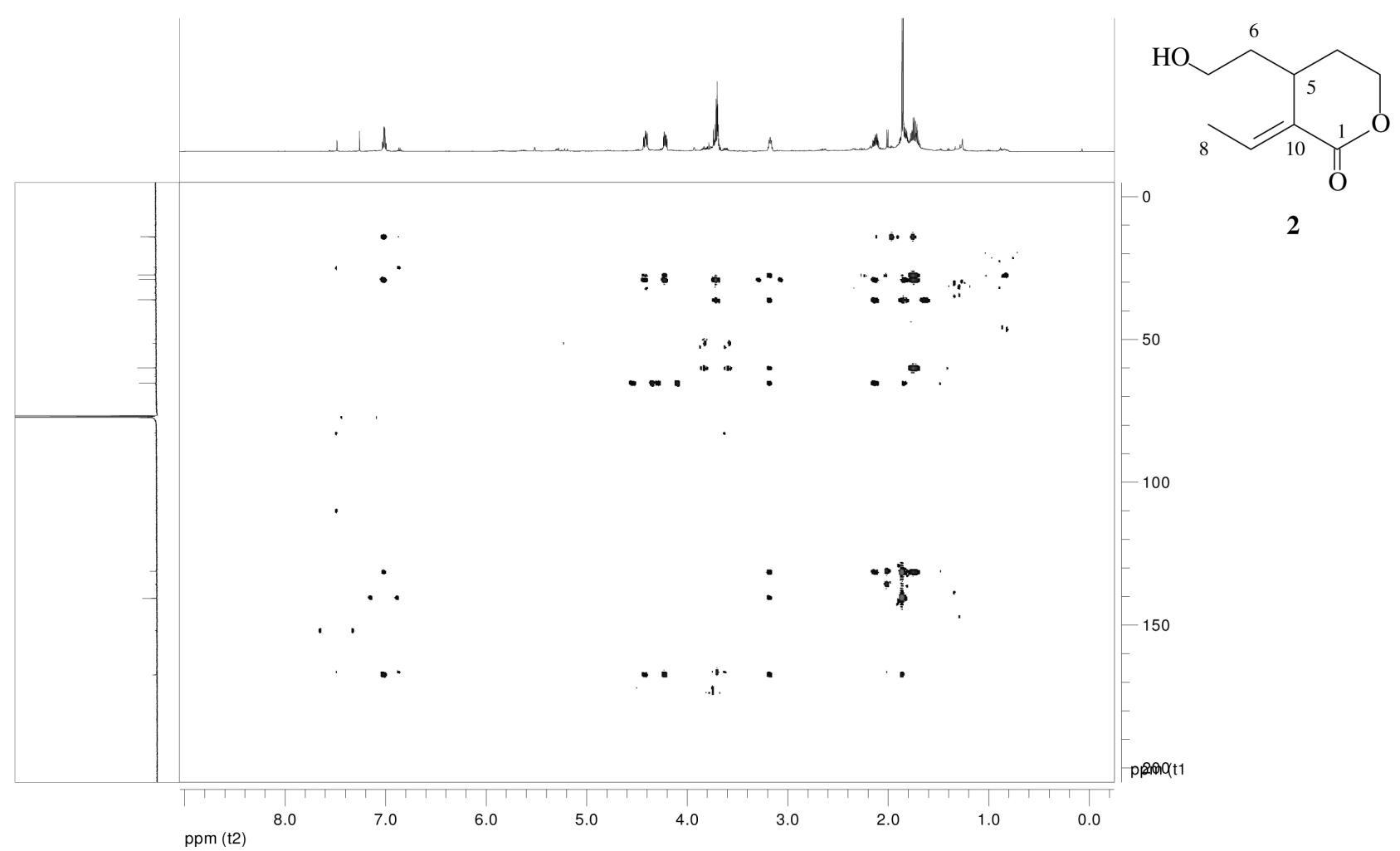

Figure S11. HMBC spectrum (150.9 MHz, $\mathrm{CDCl}_{3}$ ) of compound (2). 


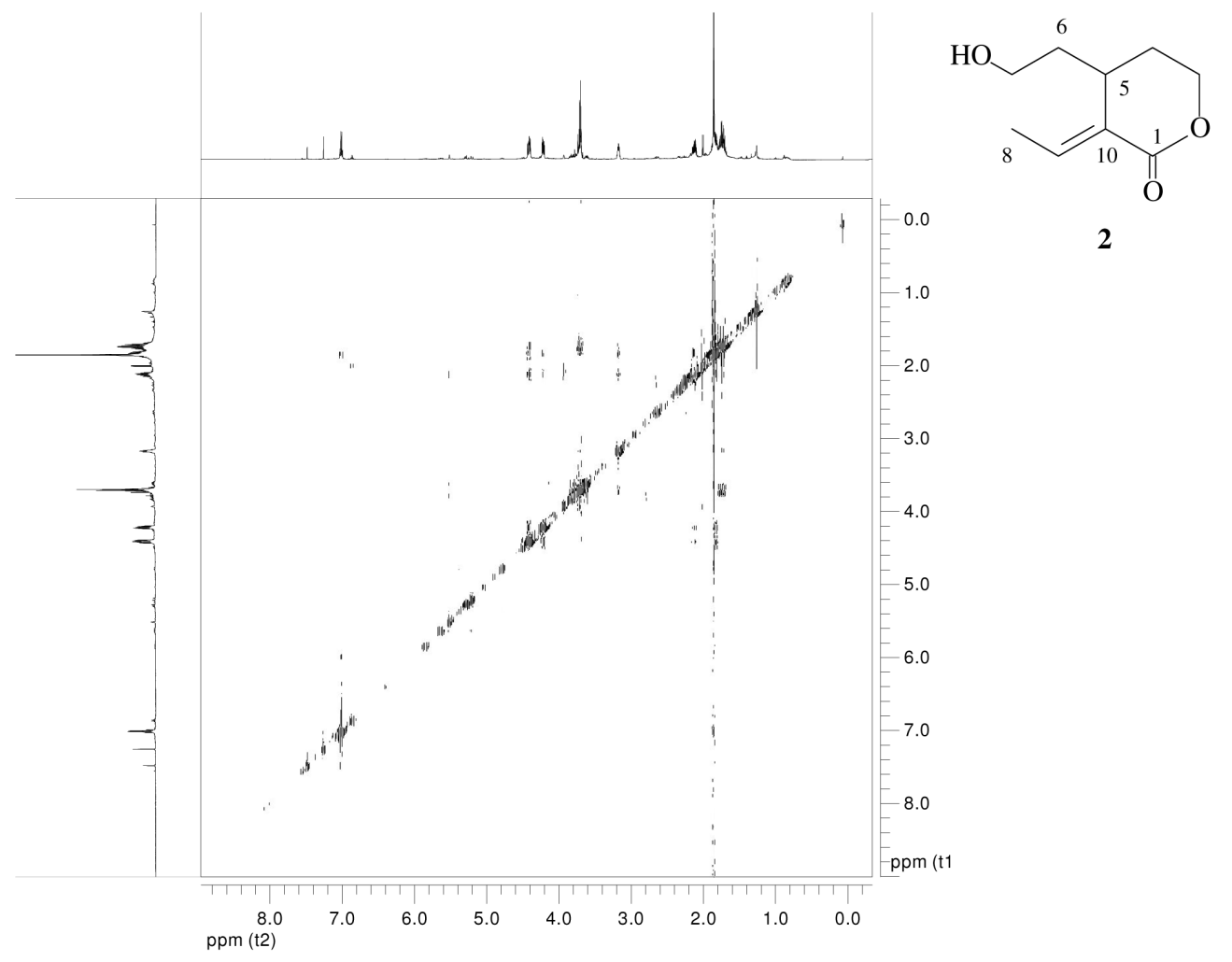

Figure S12. NOESY spectrum (600 MHz, $\mathrm{CDCl}_{3}$ ) of compound (2). 